Tropical Journal of Pharmaceutical Research March 2017; 16 (3): 515-523

ISSN: $1596-5996$ (print); 1596-9827 (electronic)

(C) Pharmacotherapy Group, Faculty of Pharmacy, University of Benin, Benin City, 300001 Nigeria.

All rights reserved.

Available online at http://www.tjpr.org

Original Research Article

http://dx.doi.org/10.4314/tjpr.v16i3.4

\title{
Eleutheroside $E$ inhibits doxorubicin-induced inflammation and apoptosis in rat cardiomyocytes by modulating activation of NF-kB pathway
}

\author{
Zheng $\mathrm{Wu}^{1}$, Wenzheng $\mathrm{Li}^{1}$, Yuhua Sun ${ }^{2}$, Kun $\mathrm{Fu}^{1}$ and Shujuan Cheng ${ }^{1 *}$ \\ ${ }^{1}$ Department of 28 Division of Cardiovascular, Beijing Anzhen Hospital, Capital Medical University, Beijing Institute of Heart, \\ Lung and Blood Vessel Diseases, ${ }^{2}$ Department of Blood Diseases, Peking University First Hospital, Beijing 100069, China \\ *For correspondence: Email: sjcheng6@163.com; Tel: 010-64456260
}

Received: 25 October 2016

Revised accepted: 16 February 2017

\begin{abstract}
Purpose: To identify the effects of eleutheroside $E$ (EE) on apoptosis and inflammation induced by doxorubicin (DOX) in H9c2 cells and to investigate the underlying mechanisms.

Methods: The effect of EE on H9c2 cell viability was determined using Cell Counting Kit-8 (CCK8). EE effect on DOX-induced apoptosis and inflammation in H9c2 cells was studied by comparison between cells treated with DOX alone and DOX $+E E$; the relationship between EE effects and $N F-K B$ signaling pathway was evaluated by the addition of NF-KB inhibitor PDTC. Cell apoptosis was examined by flow cytometry while IL-1 $\beta, I L-6$, and TNF- $\alpha$ levels were determined by ELISA. The phosphorylation level of NF-KB p65 was measured by Western blot.

Results: Compared with control group, cell viability was notably elevated after treatment with 50-100 $\mu M$ EE for 48 or 72 h. DOX induced higher rates of cell apoptosis in H9c2 cells (29.5 $\pm 3.56 \%$ ) compared with control group (6.39 $\pm 0.67 \%)$; however, with EE pretreatment (50 and $80 \mu \mathrm{M})$, apoptosis rate decreased to $16.8 \pm 2.16$ and $13.54 \pm 2.08 \%$, respectively, which are significantly lower than that of DOX group; furthermore, the levels of IL-1 $\beta, I L-6$, and TNF- $\alpha$ also reduced. In addition, DOX-induced phosphorylation of NF-KB p65 was suppressed by EE pretreatment (10, 50 and $80 \mu M)$ to $11.51 \pm 1.25$, $40.2 \pm 5.17$ and $52.97 \pm 6.74 \%$, respectively

Conclusion: The results suggest that EE treatment reduced DOX-induced apoptosis and inflammation by interacting with NF-KB signaling pathway. This finding sheds some light on probable new strategies on the application of DOX for cancer treatment.
\end{abstract}

Keywords: Eleutheroside E, Doxorubicin, Inflammation, Apoptosis, Cardiomyocytes, NF-KB

Tropical Journal of Pharmaceutical Research is indexed by Science Citation Index (SciSearch), Scopus, International Pharmaceutical Abstract, Chemical Abstracts, Embase, Index Copernicus, EBSCO, African Index Medicus, JournalSeek, Journal Citation Reports/Science Edition, Directory of Open Access Journals (DOAJ), African Journal Online, Bioline International, Open-J-Gate and Pharmacy Abstracts

\section{INTRODUCTION}

Doxorubicin (DOX), one of the most commonly used anti-cancer drugs, possesses therapeutic effects for a variety of cancers, including leukemia, lymphoma, soft tissue sarcomas and solid tumors [1-4]. However, its clinical use is limited by a dose-related acute and chronic cardiotoxicity $[5,6]$. While the mechanism of DOX-induced cardiotoxicity still remains unclear, recent evidence have demonstrated that oxidative stress and cardiac inflammation were involved in the process [7-10]. Therefore 3hydroxy-3-methylglutaryl coenzyme A (reductase inhibitor, which has anti-inflammatory and antioxidative effects) has been used to lessen the cardiotoxicity of DOX in mice [11]. In addition, both suppressed cardiac cytokine activation and lipid peroxidation have been shown to play critical roles in improving left ventricular (LV) 
function in a mouse model of DOX-induced cardiotoxicity $[8,11]$.

Eleutheroside $E$ (EE), an active component of Eleutherococcus senticosus, is known to exert an anti-inflammatory effect by inhibiting inflammatory cytokine expression [12,13]. However, the effects of EE on DOX-induced injury to cardiomyocytes and its underlying mechanism remain unclear.

In this study, we identified the effects of EE on H9c2 cell proliferation DOX-induced apoptosis and associated inflammation. Its effect on phosphorylation level of NF-KB p65 was also investigated to understand the role of NF-KB signaling pathway in the protective effect of $E E$.

\section{EXPERIMENTAL}

\section{Eleutheroside E}

EE (CAS: 39432-56-9) white crystalline powder with a purity of $\geq 98 \%$ was purchased from Chroma Biotechnology Co. Ltd. (Chengdu, China). It was dissolved in appropriate amount of dimethylsulfoxide (DMSO) and diluted to target concentrations before utilization, with the final DMSO concentrations below $0.5 \%$.

\section{Cell culture, cell grouping and viability assay}

H9c2 cardiac cells were cultured in 96-well plates containing DMEM-F12 medium supplemented with $10 \% \mathrm{FBS}$ and maintained at $37^{\circ} \mathrm{C} / 5 \% \mathrm{CO}_{2}$. To examine the effects of EE on DOX (SigmaAldrich, St. Louis, MO, USA) induced injury, $\mathrm{H} 9 \mathrm{c} 2$ cells were divided into five groups: control, DOX $(1 \mu \mathrm{M})$, EE $(10 \mu \mathrm{M})$, EE $(50 \mu \mathrm{M})$ and $\mathrm{EE}(80$ $\mu \mathrm{M})$ groups. In all EE groups, H9c2 cardiac cells were pretreated with various concentrations of EE $(10,50$ and $80 \mu \mathrm{M})$ for $2 \mathrm{~h}$ prior to DOX (1 $\mu \mathrm{M})$ treatment.

In order to further study whether the protective effects of EE were associated with the inhibition of NF-KB signaling, $\mathrm{H} 9 \mathrm{c} 2$ cells were divided into six groups named as control, PDTC, DOX, EE $(50 \mu \mathrm{M})$, EE $(50 \mu \mathrm{M})+\mathrm{DOX}$ and PDTC + DOX groups. PDTC group, DOX group, and EE group was treated with $10 \mu \mathrm{M}$ PDTC, $1 \mu \mathrm{M}$ DOX, and $50 \mu \mathrm{M} E E$, respectively. Cells in DOX + EE and PDTC +DOX groups were pretreated with EE (50 $\mu \mathrm{M})$ or PDTC $(10 \mu \mathrm{M})$ for $2 \mathrm{~h}$ prior to DOX treatment.

For viability assay, Cell Counting Kit-8 (CCK8) (Sigma-Aldrich, St. Louis, MO, USA) solution (10 $\mu \mathrm{L})$ was added to each well at 1/10 dilution, followed by incubation of 2 hours. Absorbance was measured at $450 \mathrm{~nm}$ with a microplate reader (Thermo Fisher Scientific, Waltham, MA, USA).

\section{Determination of cell apoptosis}

Cell apoptosis was detected with a flow cytometer (FCM) using an Annexin V-FITC apoptosis detection kit (Zhongze, Shanghai, China) following the manufacturer's instructions. After DOX treatment, H9c2 cells were harvested, washed with cold PBS, and re-suspended in 500 $\mu \mathrm{l}$ binding buffer. Then $5 \mu \mathrm{L}$ of Annexin $\mathrm{V}$ stock solution was added and the cells were incubated for $10 \mathrm{~min}$ at $4^{\circ} \mathrm{C}$. Propidium iodide (PI, $5 \mu \mathrm{L} /$ well) was added to the cells, which were immediately analyzed using a FACS-Calibur flow cytometer (Becton Dickinson, San Jose, CA, USA).

\section{Analysis of nuclear morphology}

$\mathrm{H} 9 \mathrm{c} 2$ cells were cultured in a 6 -well plate with a cell density of $2 \times 10^{5}$ per well for $24 \mathrm{~h}$ and pretreated with different doses of EE for $2 \mathrm{~h}$ prior to DOX treatment. Cells were harvested, rinsed twice with PBS, fixed with $1 \mathrm{~mL}$ of $4 \%$ paraformaldehyde for $10 \mathrm{~min}$, and then rinsed twice with PBS (5 min/time).

After being stained with $0.5 \mathrm{ml}$ of Hoechst 33258 (Sigma, St. Louis, MO, USA) nuclear dye (10 $\mu \mathrm{M})$ for $5 \mathrm{~min}$, the cells were washed twice with PBS, then observed and photographed under an inverted fluorescence microscope (DMI3000B, Leica, Wetzlar, Germany) with the excitation and emission wavelengths of 340 and $460 \mathrm{~nm}$, respectively. Apoptotic cells were identified on the basis of nuclear morphology changes, such as chromatin condensation and fragmentation.

\section{ELISA}

H92c cells were cultured in 96-well plates. After the indicated treatments, the levels of IL-1 $\beta$, IL- 6 , and TNF- $\alpha$ in the culture media were measured using ELISA kits (Takara, Kusatsu, Japan). Each experiment was repeated at least 5 times.

\section{Extraction of cytoplasmic and nuclear proteins}

After the indicated treatment, H9c2 cells were harvested. Proteins in cytoplasm and nuclei from H9c2 cells were isolated by the NE-PER Nuclear and Cytoplasmic Extraction Kit according to the manufacturer's protocol (Thermo Fisher Scientific, Waltham, MA, USA). The cytoplasmic and nuclear protein extracts were prepared for Western blot analysis. 


\section{Western blot}

After the indicated treatments, $\mathrm{H} 9 \mathrm{c} 2$ cells were harvested, lysed, and the homogenate was centrifuged at $12,000 \mathrm{rpm}$ for $10 \mathrm{~min}$ at $4{ }^{\circ} \mathrm{C}$. The protein concentration in the supernatant was determined by the BCA protein assay kit (Thermo Fisher Scientific, Waltham, MA, USA). Equal amounts of proteins $(30 \mu \mathrm{g}$ from each sample) were separated by $12 \%$ SDS-PAGE and transferred to polyvinylidene difluoride (PVDF) membranes. The membranes were blocked with $5 \%$ free-fat milk in TBS-T for $1 \mathrm{~h}$ at room temperature, and then incubated with primary antibodies against p65, p-p65 (1: 4,000) (Cell Signaling Technology, Beverly, MA, USA), iNOS (1: 1,000) (Santa Cruz Biotechnology, Santa Cruz, CA, USA), or GAPDH with gentle agitation at $4{ }^{\circ} \mathrm{C}$ for overnight. After that, the membranes were incubated with secondary antibodies for $1.5 \mathrm{~h}$ at room temperature. After three washes with TBS-T, the membranes were developed using enhanced chemiluminescence (ECL, Thermo Scientific, Shanghai, China) and were then exposed to X-ray films. X-ray films were scanned and analyzed with ImageJ 1.41p software (National Institutes of Health, Bethesda, Maryland, USA) for protein quantification.

\section{Statistical analysis}

All results were presented as mean \pm SD. Data were analyzed using a SPSS 13.0 statistical package. Multiple comparisons for data were performed by one-way ANOVA, followed by Dunnett's test. A value of $p<0.05$ was considered statistically significant.

\section{RESULTS}

\section{Effect of EE on H9c2 cell proliferation}

We first investigated the effect of EE on H9c2 cell proliferation. As shown in Figure 1, EE promoted $\mathrm{H} 9 \mathrm{c} 2$ cell proliferation in a timedependent manner. Cell viability was notably elevated after being treated with 50-100 $\mu \mathrm{M}$ for $48 \mathrm{~h}$ or $72 \mathrm{~h}$, while no significant difference was seen among these samples. Therefore 10, 50 and $80 \mu \mathrm{M}$ of EE were used to carry out further investigations.

\section{EE inhibits $\mathrm{H} 9 \mathrm{c2}$ cell apoptosis induced by DOX}

We then looked into whether or not EE influenced $\mathrm{H} 9 \mathrm{c} 2$ cell apoptosis induced by DOX. The effect of EE on DOX-induced H9c2 cell apoptosis are shown in Figure 2. DOX gave rise to higher rates of cell apoptosis in $\mathrm{H} 9 \mathrm{c} 2$ cells $(29.5 \pm 3.56 \%)$ compared with control group $(6.39 \pm 0.67 \%$. Pretreatment with EE (50 and 80 $\mu \mathrm{M})$ for $2 \mathrm{~h}$ decreased the apoptosis rates of the $\mathrm{H} 9 \mathrm{c} 2$ cells to $16.8 \pm 2.16$ and $13.54 \pm 2.08 \%$, respectively.

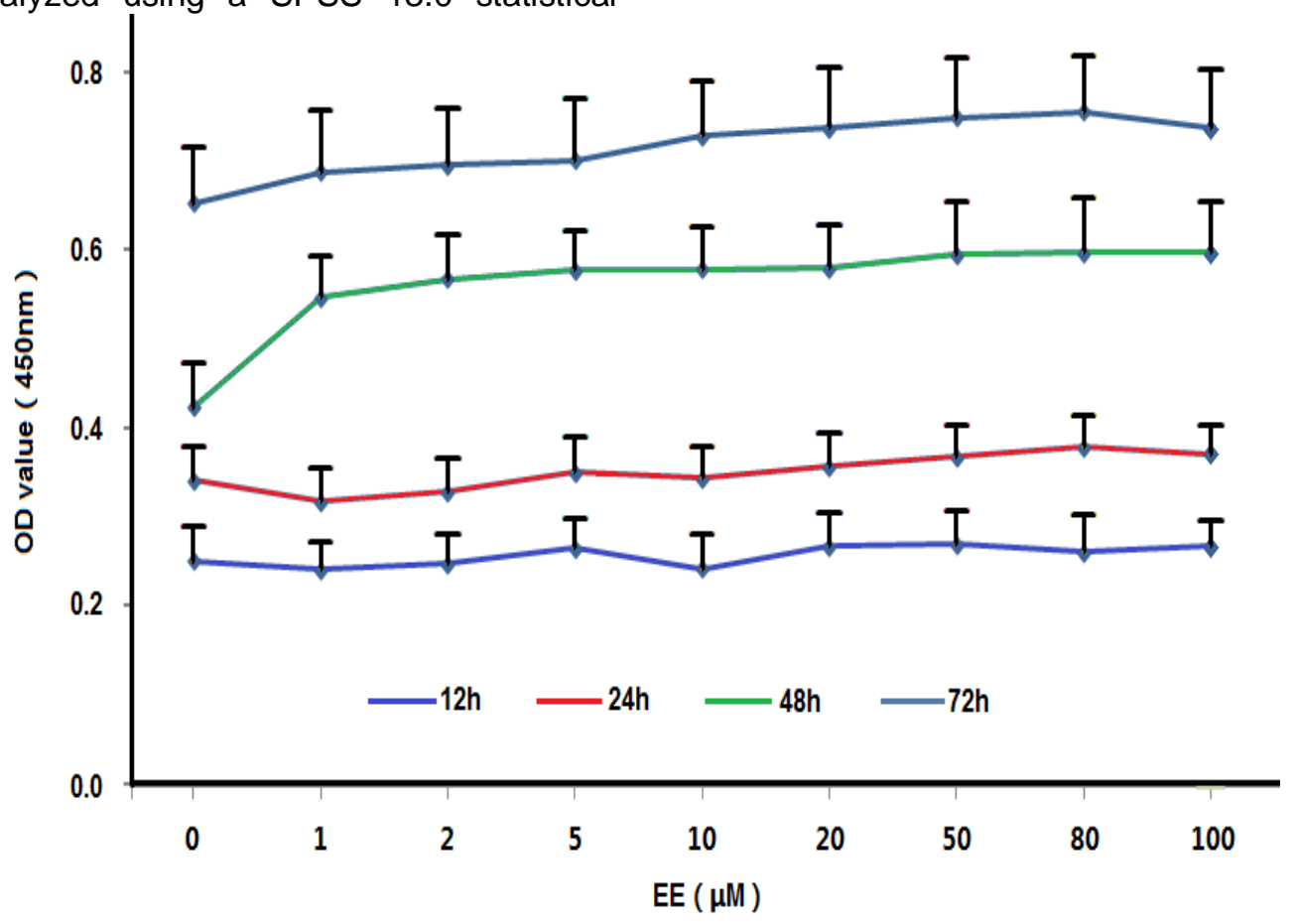

Figure 1: Effect of EE on the viability of H9c2 cardiac cells. H9c2 cardiac cells were exposed to various concentrations of $\operatorname{EE}(0,1,2,5,10,20,50$ and $100 \mu \mathrm{M})$ for $12,24,48$ and $72 \mathrm{~h}$, and the cell viability was determined by CCK8 assay. Data were expressed as mean $\pm \mathrm{SD}, \mathrm{n}=6,{ }^{*} p<0.05$, versus the control 
Morphological changes of $\mathrm{H} 9 \mathrm{c} 2$ cells were observed with Hoechst 33258 staining (Figure 3). Chromatin in normal cells showed a wellproportioned low density of fluorescence. H9c2 cells treated with DOX showed typical apoptosis characteristics with a concentrated compact

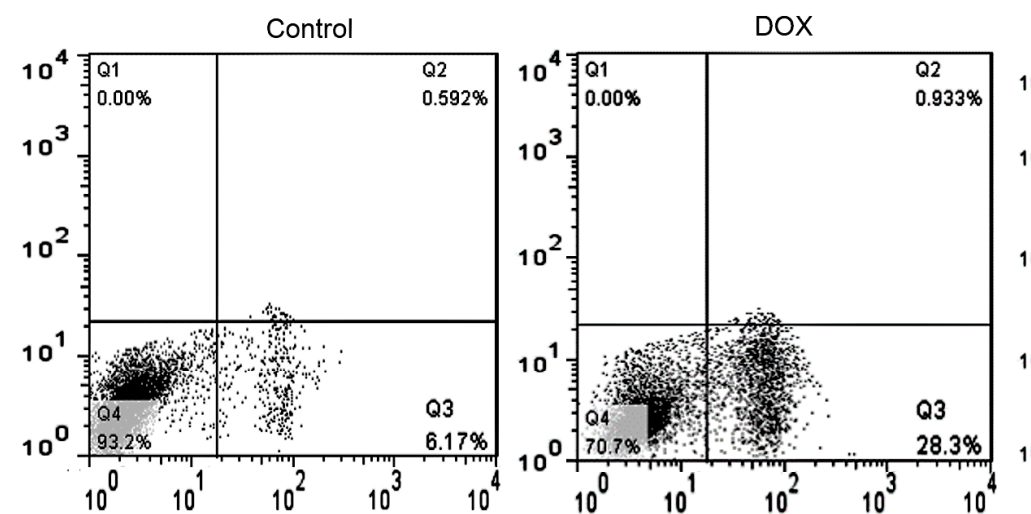

density of fluorescence in the nucleus. The symptoms of apoptosis were significantly decreased in the EE pretreatment groups, indicating EE significantly inhibits $\mathrm{H} 9 \mathrm{c} 2$ cell DOXinduced apoptosis of H9c2 cell.

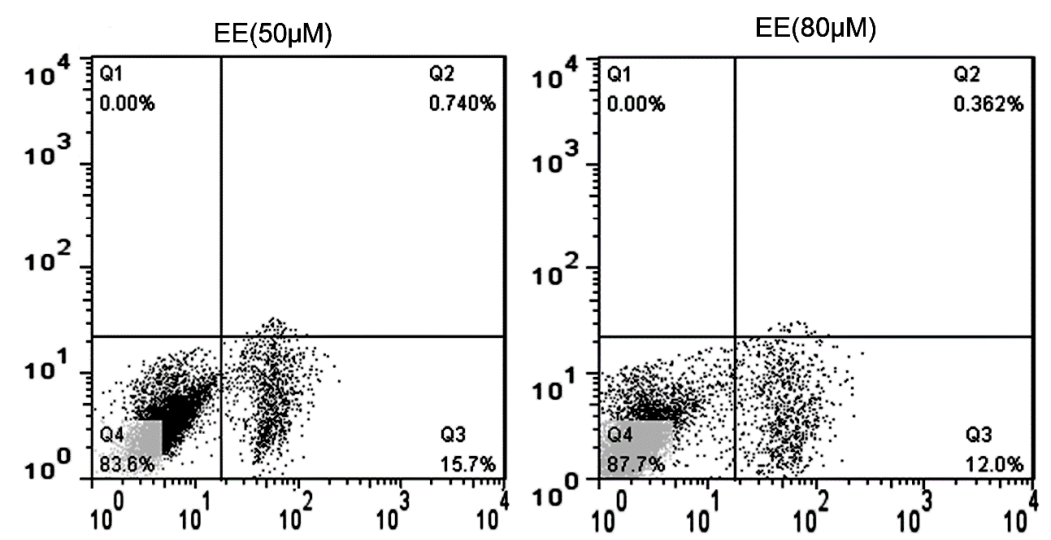

Figure 2: Protective effect of EE on DOX-induced apoptosis. H9c2 cardiac cells were treated with various doses of EE $(10,50$ and $80 \mu \mathrm{M})$ for $2 \mathrm{~h}$, then exposed to DOX for $24 \mathrm{~h}$. Annexin $V$ assay was used for apoptosis detection.

Control

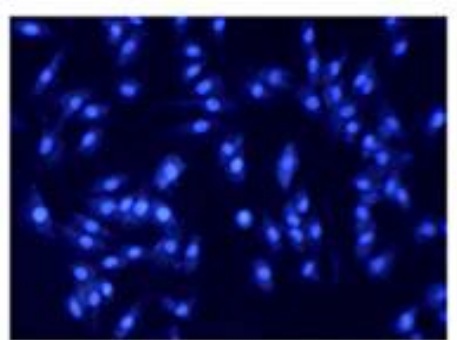

DOX

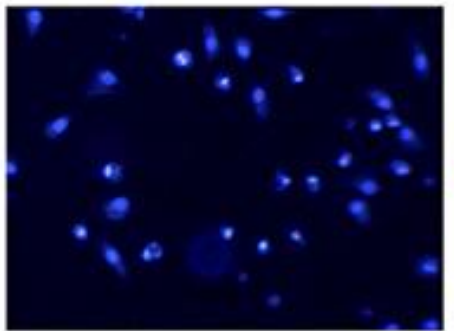

$\mathrm{EE}(10 \mu \mathrm{M})$

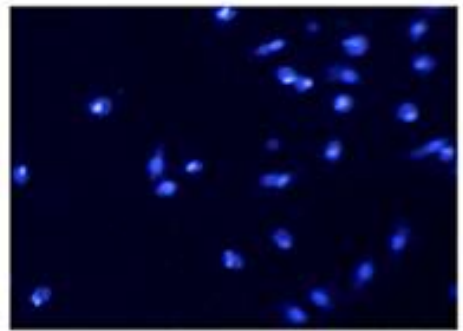

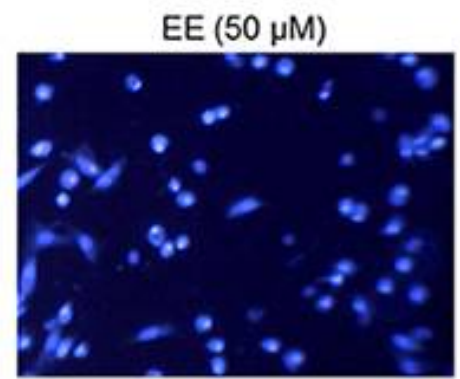

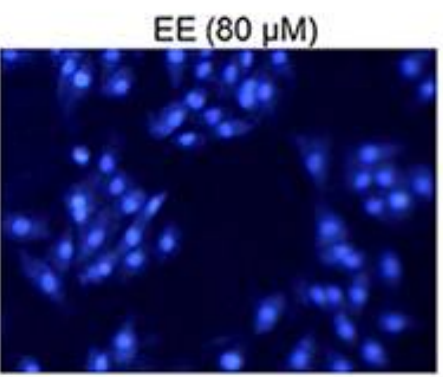

Figure 3: Effects of EE on nuclear morphology. H9c2 cardiac cells were treated with various doses of EE (10,50 and $80 \mu \mathrm{M}$ ) for $2 \mathrm{~h}$, then exposed to DOX for $24 \mathrm{~h}$. Cells were stained with Hoechst 33258 
EE suppresses IL-1 $\beta$, IL- 6 and TNF- $\alpha$ levels induced by DOX

Next we examined EE effect on DOX-induced production of inflammatory cytokines. The levels of secreted IL-1 $\beta, I L-8$, and TNF- $\alpha$ in the culture media were determined by ELISA. As shown in Figure 4, when compared with control group, the levels of IL-1 $\beta$, IL- 6 , and TNF- $\alpha$ in DOX treated groups were significantly increased by $174.5 \pm$ $16.2,74.9 \pm 8.47$ and $79.8 \pm 9.61 \%$, respectively. However, 10, 50 and $80 \mu \mathrm{M}$ of EE pretreatment remarkably reduced $\mathrm{IL}-1 \beta$ and TNF- $\alpha$ levels in a dose-dependent manner, while 50 and $80 \mu \mathrm{M}$ of EE pretreatment significantly decreased IL-6 level in compared with DOX treated groups.

\section{EE suppresses phosphorylation of NF-KB p65 induced by DOX}

In order to elucidate the mechanism of protective effect of $E E$, we next examined the impact on phosphorylation level of NF-kB p65, which was detected by Western blot and the results are shown in Figure 5. The phosphorylation level of NF-KB p65 in DOX group was increased by $181.22 \pm 18.8 \%$ compared with control group. EE pretreatment $(10,50$ and $80 \mu \mathrm{M})$ remarkably reduced the phosphorylation of NF-KB p65 by $11.51 \pm 1.25,40.2 \pm 5.17$ and $52.97 \pm 6.74 \%$, respectively.
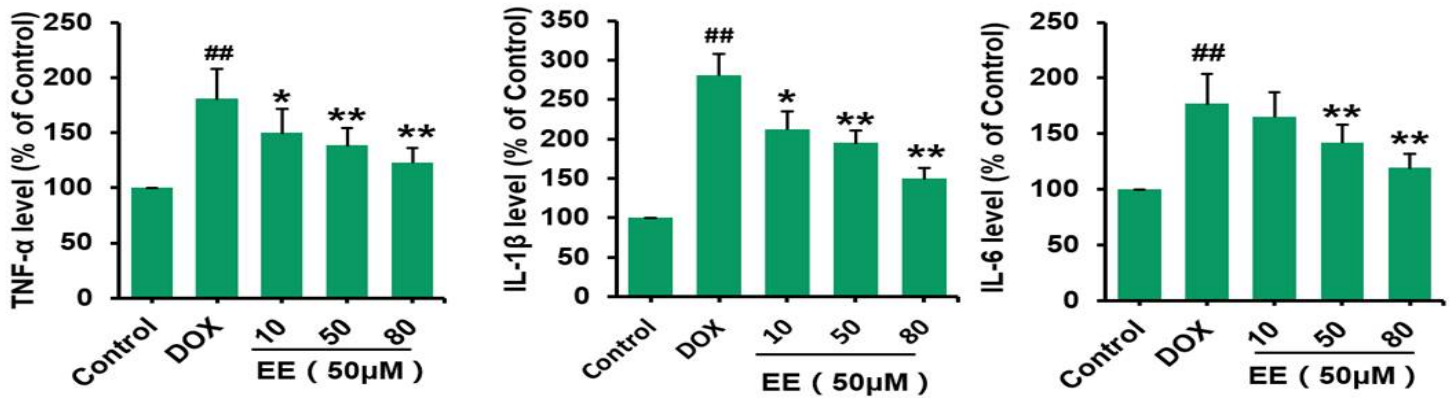

Figure 4: EE suppresses the IL-1 $\beta, \mathrm{IL}-6$, and TNF- $\alpha$ levels induced by DOX. H9c2 cardiac cells were treated with various doses of EE $(10,50$ and $80 \mu \mathrm{M})$ for $2 \mathrm{~h}$, then exposed to DOX for $24 \mathrm{~h}$. The IL-1 $\beta$, IL-6, and TNF- $\alpha$ levels in H9c2 cardiac cells were determined by ELISA. Data are expressed as mean $\pm \mathrm{SD}, \mathrm{n}=6,{ }^{\# \#} p<0.01$, versus the control; ${ }^{* \star} p<0.01$, versus the DOX groups
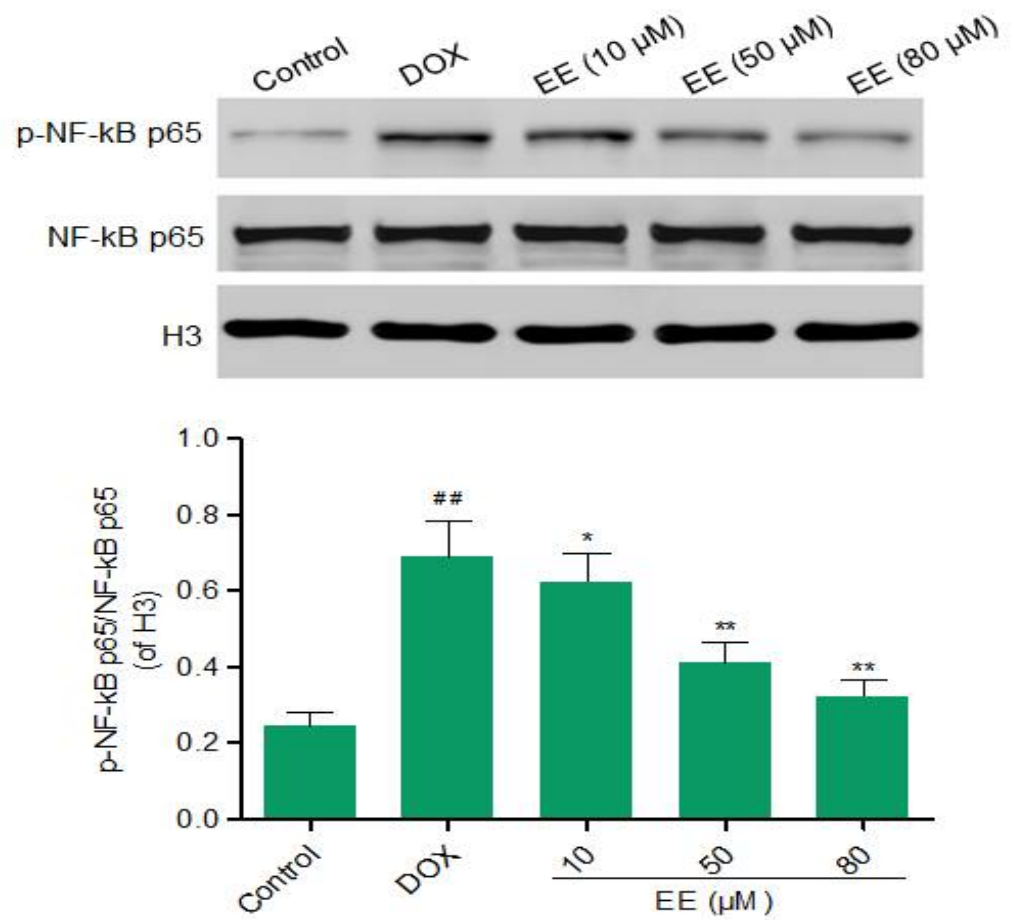

Figure 5: Effect of EE on NF-kB p65 phosphorylation. H9c2 cardiac cells were treated with various doses of EE $(10,50$ and $80 \mu \mathrm{M})$ for $2 \mathrm{~h}$, then exposed to DOX for $24 \mathrm{~h}$. The phosphorylation level of NF-KB p65 was assessed by western blot analysis. GAPDH was used as internal control. Data were expressed as mean $\pm \mathrm{SD}, \mathrm{n}=6,{ }^{\# \#} p<$ 0.01 , versus the control; ${ }^{*} p<0.05,{ }^{* *} p<0.01$ versus the DOX group 
EE attenuates DOX-induced apoptosis and inflammatory cytokine expressions in $\mathrm{H} 9 \mathrm{c2}$ cells via interaction with NF-KB signaling pathway

To further explore the mechanism by which EE alleviates DOX induced apoptosis and inflammation of H9c2 cells, H9c2 cells were pretreated with PDTC (a specific inhibitor of NF$\mathrm{KB})$ and $\mathrm{EE}(50 \mu \mathrm{M})$ prior to DOX treatment. As shown in Figure 6, there was no significant difference in apoptosis rates between control group and PDTC group. Interestingly, while EE pretreatment $(50 \mu \mathrm{M})$ effectively decreased $\mathrm{H} 9 \mathrm{c} 2$ cell apoptosis in DOX+EE group as compared with DOX group, the apoptosis rate of the PDTC $+\mathrm{DOX}+\mathrm{EE}$ group (25.2 $\pm 3.79 \%)$ was
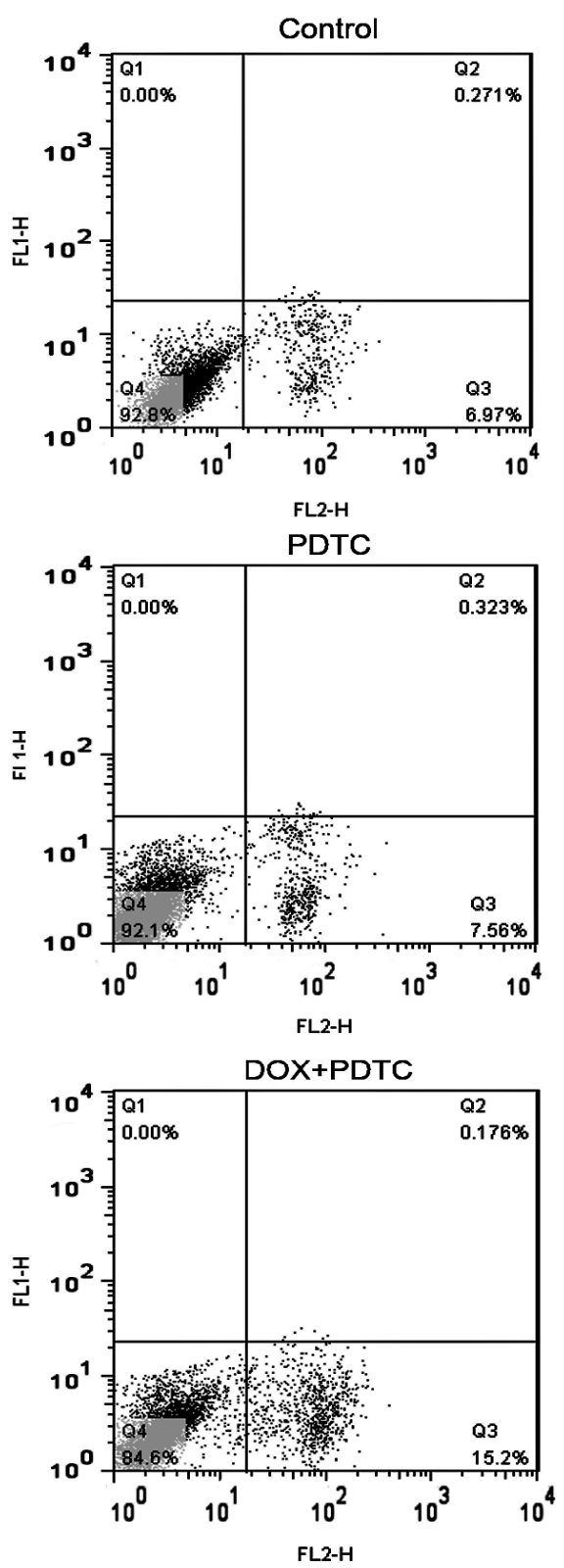

comparable to that of DOX group $(27.4 \pm 3.56$ $\%)$, suggesting that the effect of $E E$ was much less effective in the presence of PDTC, therefore it can be concluded that the protective effect of EE is associated with NF-KB signaling pathway.

In addition, the levels of secreted IL-1 $\beta$, IL-8, and TNF- $\alpha$ in the culture media was measured by ELISA. Similarly, no obvious difference in IL-1 $\beta$, IL-8 and TNF- $\alpha$ levels was seen between PDTC $+\mathrm{DOX}+\mathrm{EE}$ group and DOX group, indicating that $E E$ failed to reduce the level of inflammatory cytokines induced by DOX in the presence of PDTC while it effectively decreased the level of inflammatory cytokines in DOX+EE group, as compared with DOX group.
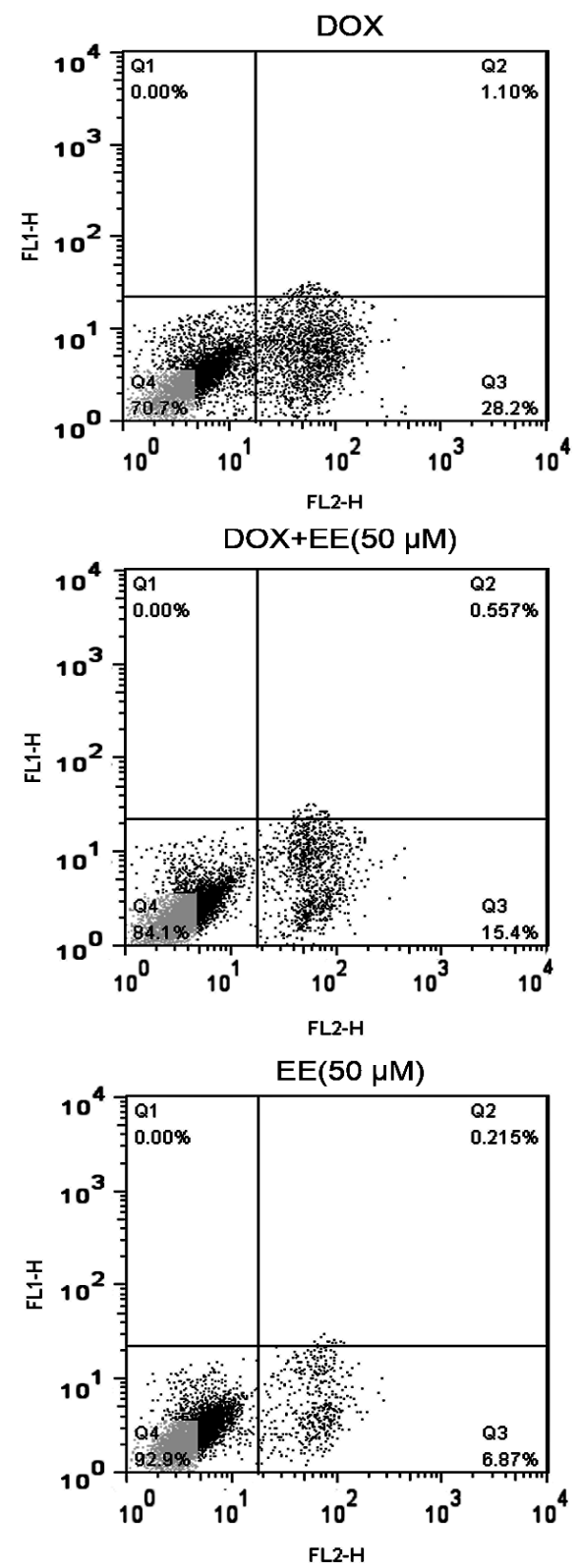

Figure 6: EE attenuates DOX induced apoptosis of $\mathrm{H} 9 \mathrm{c} 2$ cells through regulating the phosphorylation of NF-KB p65. Annexin $V$ assay was used for apoptosis detection 

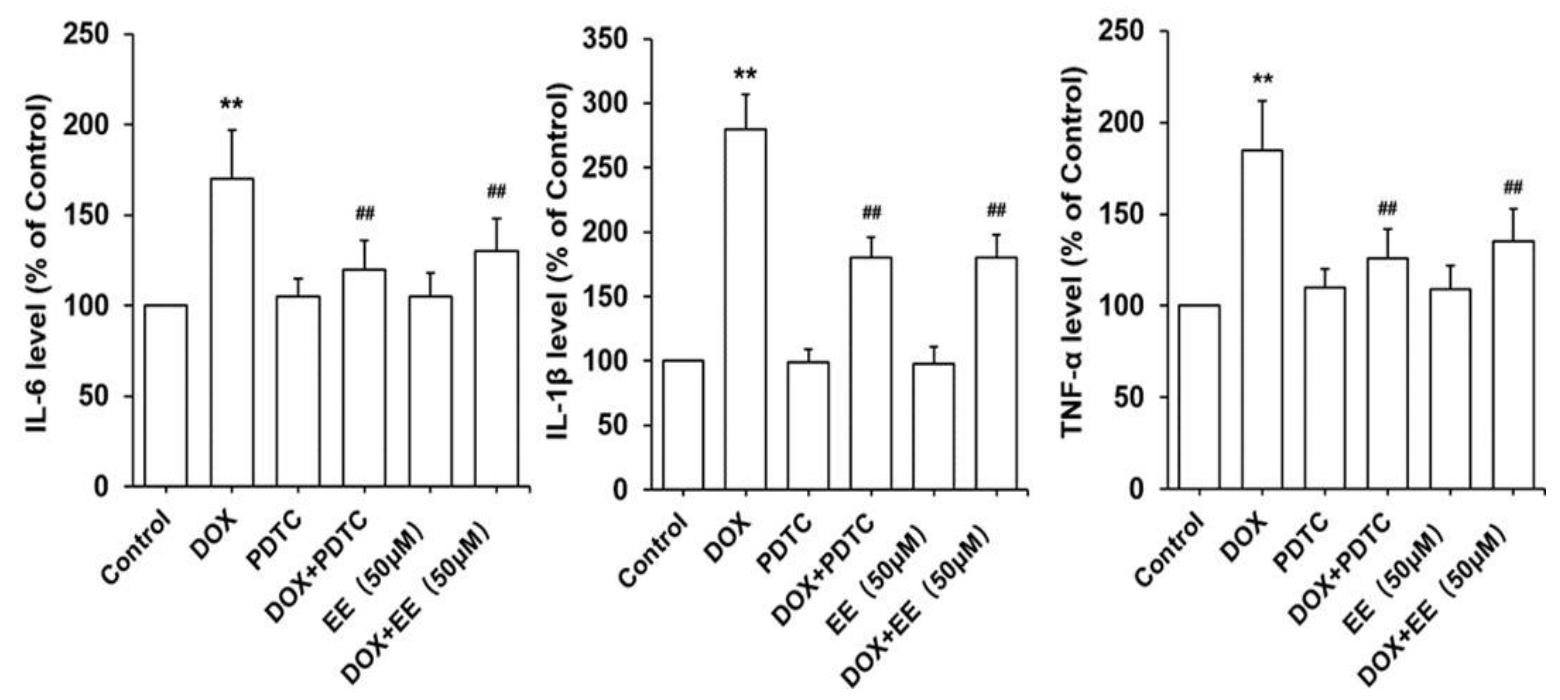

Figure 7: $\mathrm{EE}$ attenuates DOX induced cytokine production in $\mathrm{H} 9 \mathrm{c} 2$ cells through regulating the phosphorylation of NF-KB p65. IL-1 $\beta$, IL-6 and TNF- $\alpha$ levels in cells were detected by ELISA. Data were expressed as mean \pm $\mathrm{SD}, \mathrm{n}=6, \# \# p<0.01$, versus the control; ${ }^{* *} p<0.01$ versus the DOX groups

\section{DISCUSSION}

Our study demonstrated that EE promoted cell proliferation in a dose dependent manner and that EE pretreatment decreased the apoptosis rate and attenuated the inflammation of $\mathrm{H} 9 \mathrm{c} 2$ cells induced by DOX treatment. Furthermore, the EE exerted its protective effect of on DOXinduced apoptosis and inflammation in $\mathrm{H} 9 \mathrm{c} 2$ cells by regulating NF-KB signaling pathway.

DOX is reported to induce increases in the production of inflammatory cytokines such as IL$1 \beta$, IL- 6 and TNF- $\alpha$. In our experimental model, DOX also elicited an inflammatory response with an obvious increase in the production of IL-1 $\beta$, IL-6, and TNF- $\alpha$. EE could inhibit cytokine production produced by DOX, however this effect was greatly diminished inH9c2 cells pre-treated with PDTC, indicating that the phosphorylation of NF-kB p65 was responsible for the protecting role of EE on DOX-induced effects.

$\mathrm{IL}-1 \beta$ is an initiator cytokine and plays a vital role in the regulation of inflammation response [15]. It has been shown to contribute to the accumulation of IL-6 and GCSF as well as cardiotoxicity induced by DOX.[16-18].

Recently, Zhu et al reported that the DOX treatment highly induced the expression levels of the IL-1 $\beta$ and IL-1 type 1 receptor (IL-1R1) and that the recombinant human IL-1 receptor antagonist (rhlL-1Ra) inhibited the DOX-induced acute cardiotoxicity in mice [19]. This suggests the involvement of $\mathrm{IL}-1 \beta$ in DOX-induced cardiotoxicity. NF-kB activates COX-2 expression in response to multiple cytokines and growth factors, and participates in DOX-induced cardiomyocyte injury [20]. Thus, elucidating whether there is an interaction between IL-1 $\beta$ and the NF-KB pathway may lead to a method for ameliorating the inflammatory consequences of DOX.

In this study, we found that DOX-induced IL-1 $\beta$ expression and phosphorylation of NF-KB p65 expression decreased significantly with $\mathrm{EE}$ pretreatment, suggesting the involvement of the $\mathrm{IL}-1 \beta$ in the activation of the NF-KB pathway. Combined with the result that pretreatment with PDTC inhibits the DOX-induced increase in IL-1 $\beta$ levels, it was revealed that there is a positive interaction between the NF-KB pathway and IL$1 \beta$ during the development of inflammation and cytotoxicity induced by DOX. We further found that PDTC also decreases the apoptosis rate and the levels of secreted IL-1 $\beta, I L-6$, and TNF-ain the culture medium. There is no significant difference between the PDTC and PDTC + EE $(50 \mu \mathrm{M})$ treatments. The results suggest that the protective effects of EE on DOX induced apoptosis and inflammation contribute to the suppression of the phosphorylation of NF-KB p65. Therefore, EE can be employed as a new agent for the myocardial inflammation treatment.

\section{CONCLUSION}

The findings of this study suggested that EE decreased $\mathrm{H} 9 \mathrm{c} 2$ apoptosis as well as the production of IL- $1 \beta$, IL- 6 and TNF- $\alpha$ induced by DOX by suppressing the phosphorylation of NF- 
KB p65. These findings may provide new insights into the development of novel therapies for myocardial inflammation.

\section{DECLARATIONS}

\section{Conflict of Interest}

No conflict of interest associated with this work.

\section{Contribution of Authors}

The authors declare that this work was done by the authors named in this article and all liabilities pertaining to claims relating to the content of this article will be borne by them.

\section{Open Access}

This is an Open Access article that uses a funding model which does not charge readers or their institutions for access and distributed under the terms of the Creative Commons Attribution License (http://creativecommons.org/licenses/by 14.0) and the Budapest Open Access Initiative (http://www.budapestopenaccessinitiative.org/rea d), which permit unrestricted use, distribution, and reproduction in any medium, provided the original work is properly credited.

\section{REFERENCES}

1. John JV, Jeong $Y I$, Johnson RP, Heo MS, Kang D, Kim I: Cell specific doxorubicin delivery through the temperature responsive lipopolymer nanocarriers engineered by the combination of RAFT polymerization and click chemistry. J Control Release 2015; 213: e59.

2. Liu L, Yu $P$, Zhang $Y, W u B$, Cui $C, W u M$, Wang $C X$, Zhuo RX, Huang SW: Doxorubicin-conjugated magnetic iron oxide nanoparticles for $\mathrm{pH}$-sensitive and magnetic responsive drug delivery. J Control Release 2015; 213: e67.

3. Szwed M, Wrona D, Kania KD, Koceva-Chyla A, Marczak A: Doxorubicin-transferrin conjugate triggers prooxidative disorders in solid tumor cells. Toxicol In Vitro 2016; 31: 60-71.

4. Zhang Y, Yu J, Zhang L, Cai J, Cai D, Lv C: Enhanced anti-tumor effects of doxorubicin on glioma by entrapping in polybutylcyanoacrylate nanoparticles. Tumour Biol 2016; 37:2703-2708.

5. Zheng $K$, Li R, Zhou X, Hu $P$, Zhang $Y$, Huang $Y$, Chen $Z$, Huang $M$ : Dual actions of albumin packaging and tumor targeting enhance the antitumor efficacy and reduce the cardiotoxicity of doxorubicin in vivo. Int $J$ Nanomedicine 2015; 10:5327-5342.

6. Xing $M$, Yan F, Yu S, Shen P: Efficacy and cardiotoxicity of liposomal Doxorubicin-Based chemotherapy in advanced breast cancer: A Meta-Analysis of ten randomized controlled trials. PLOS ONE 2015;10: e133569.

7. Mantawy EM, El-Bakly WM, Esmat A, Badr AM, ElDemerdash E: Chrysin alleviates acute doxorubicin cardiotoxicity in rats via suppression of oxidative stress, inflammation and apoptosis. Eur J Pharmacol 2014; 728:107-118.

8. Thandavarayan RA, Giridharan VV, Arumugam S, Suzuki $K$, Ko KM, Krishnamurthy $P$, Watanabe $K$, Konishi $T$ : Schisandrin $B$ prevents doxorubicin induced cardiac dysfunction by modulation of DNA damage, oxidative stress and inflammation through inhibition of MAPK/p53 signaling. PloS One 2015;10: e119214.

9. Ruan $Y$, Dong $C$, Patel J, Duan $C$, Wang $X, W u X$, Cao $Y$, Pu L, LU D, Shen T, Li J: SIRT1 suppresses doxorubicin-induced cardiotoxicity by regulating the oxidative stress and p38MAPK pathways. Cell Physiol Biochem 2015; 35: 1116-1124.

10. El-Sayed E, Mansour AM, Abdul-Hameed MS: Thymol and carvacrol prevent Doxorubicin-Induced cardiotoxicity by abrogation of oxidative stress, inflammation, and apoptosis in rats. $J$ Biochem Mol Toxicol 2016; 30: 37-44.

11. Memon S, Ganga HV, Masrur S, Thompson PD: The effect of HMG COA reductase inhibitors on the progression of aortic sclerosis: Review article. Conn Med 2016;80: 169-174.

12. He $C$, Chen $X$, Zhao $C$, Qie $Y$, Yan $Z$, Zhu $X$ : Eleutheroside $E$ ameliorates arthritis severity in collagen-induced arthritis mice model by suppressing inflammatory cytokine release. Inflammation 2014; 37: 1533-1543.

13. Yang $X$, Wang $Y$, Gao G: High glucose induces rat mesangial cells proliferation and MCP-1 expression via ROS-mediated activation of NF-kappaB pathway, which is inhibited by eleutheroside $E$. J Recept Signal Transduct Res 2016; 36: 152-157.

14. Chen JY, Zhang L, Zhang H, Su L, Qin LP: Triggering of p38 MAPK and JNK signaling is important for oleanolic acid-induced apoptosis via the mitochondrial death pathway in hypertrophic scar fibroblasts. Phytother Res 2014; 28: 1468-1478.

15. Cavalcanti NG, Marques CD, Lins ELT, Pereira MC, Rego MJ, Duarte AL, Pitta ID, Pitta MG: Cytokine profile in gout: Inflammation driven by IL-6 and IL-18? Immunol Invest 2016, 45:1-13.

16. Kim JH, Choi YJ, Lee BH, Song MY, Ban CY, Kim J, Park J, Kim SE, Kim TG, Park SH, Kim HP, Sung YC, Kim $S C$, Shin EC: Programmed cell death ligand 1 alleviates psoriatic inflammation by suppressing IL-17A production from programmed cell death 1-high $T$ cells. J Allergy Clin Immunol 2016;137: 1466-1476.

17. Neri M, Bello S, Bonsignore A, Centini F, Fiore C, FoldesPapp Z, Turillazzi E, Fineschi V: Myocardial expression of TNF-alpha, IL-1beta, IL-6, IL-8, IL-10 and MCP-1 after a single MDMA dose administered in a rat model. Curr Pharm Biotechnol 2010;11: 413-420. 
18. Norell H, Poschke I, Charo J, Wei WZ, Erskine C, Piechocki MP, Knutson KL, Bergh J, Lidbrink E, Kiessling R: Vaccination with a plasmid DNA encoding HER-2/neu together with low doses of GM-CSF and IL-2 in patients with metastatic breast carcinoma: $A$ pilot clinical trial. J TransI Med 2010; 8:53.

19. Zhu J, Zhang J, Xiang D, Zhang Z., Zhang L., Wu M, Zhu $S$, Zhang $R$, Han, W. Recombinant human interleukin-1 receptor antagonist protects mice against acute doxorubicin-induced cardiotoxicity. European journal of pharmacology 2010; 643(2): 247-253.

20. Guo Rm, Xu WM, Lin JC, Mo LQ, Hua XX, Chen $P X, W u$ $K$, Zhang $D D$, Feng JQ: Activation of the $p 38 \mathrm{MAPK} / N F-$ $\kappa B$ pathway contributes to doxorubicin-induced inflammation and cytotoxicity in $\mathrm{H} 9 \mathrm{c} 2$ cardiac cells. Molecular medicine reports 2013; 8(2): 603-608. 